\title{
A New Era for Assessing Airway Diseases: New Insights in the Asthma Paradigm
}

\author{
J. Bellido-Casado \\ Institut de Recerca, Pneumology Department, \\ Hospital Santa Creu i Sant Pau Barcelona \\ Spain
}

\section{Introduction}

The definition of asthma is constantly being modified and redefined. New knowledge derived from molecular biology and applied immunology is very valuable in interpreting how the airway becomes diseased. At the same time, new biomarkers useful for monitoring patients and detecting inflammatory airway disease are being identified. Currently, patients whose condition is included in the spectrum of inflammatory airway diseases may be reassessed and placed into subgroups so that the biotypes, or endotypes (disease) and phenotypes (patients), form new paradigms to delineate and integrate applied knowledge to this complex and heterogeneously-expressed disease. The definition of asthma and different ways of understanding the disease undergo constant review.

\section{Asthma defined as an inflammatory airway disease}

The definition of asthma may be established using a set of characteristics that are clinical (recurrent episodes of wheezing and dyspnea), pathophysiological (variability in airflow), or immunological (chronic inflammation) (Global Initiative for Astma [GINA], 2009; British Thoracic Society Scottish Intercollegiate Guidelines Network [BTSSIGN], 2008). They may be found in patients or heterogeneous groups of patients who share these symptoms to a greater or lesser extent. Depending on the emphasis placed on a more specific predominant feature of airway dysfunction, the 'nominalist' view of the concept of asthma is more relevant. On the other hand, if several features are examined together to make the diagnosis, the more 'essentialist' aspect of the specific airway disease stands out [GINA, 2009; BTSSIGN 2008]. Thus, both definitions must be kept in mind when dealing with asthma, and determining an objective system of measurement for the quantifiable aspects that that make up either definition is required [Hargreave \& Nair, 2009]. For decades, different methods to quantify and measure the various components of asthma (symptoms, spirometry, maximum peak flow, bronchial provocation) have been used in situations of good health or illness, highlighting the complexity involved in studying, functionally, both the normal and altered airway. Not all the defining characteristics of asthma are present in all patients; moreover, they vary greatly and are often irregular in a single patient. The therapeutic response may also be different depending on the specific pathophysiological characteristics that are predominately found [Lotvall et al., 2011]. Therefore, the classification of asthma severity by 
daily medication regimen and response to treatment, as well as the different strategies and recommendations for managing patients with difficult to control asthma are essentially needed in clinical practice [Holgate \& Polosa, 2006]; otherwise they are limited. New methods based on statistical physics and fluctuation analysis can be a new strategy for assessing and predicting the risk of progression of asthma [Frey \& Suki, 2008], but monitoring of airway diseases also requires focus on foundations of the modern biology. Therefore, the application of new technological advancements and the disciplines applied to the study of inflammation, as well as the incorporation of new markers for diagnosis and the monitoring of patients affected by asthma, inspires optimism in the challenge to find a better conceptual understanding of asthma using a dynamic approach that continuously changes and at the same time is more significant than that achieved by mere verification.

In this chapter, specific aspects of the new contributions to the monitoring of asthma and the new research using defined groups of patients to study interrelated heterogeneous aspects of asthma will be described and discussed. These new contributions have modified the approach to grouping and reclassifying characteristics that are clinical, pathophysiological and biological as a whole, and allow for a new definition of asthma in terms of 'phenotypes' and 'endotypes' [Anderson, 2008a; Wenzel, 2006]. Although the addition of these new terms to the definition of asthma may be seen as a conceptual breakthrough, caution must be exercised. For example, new biological knowledge about the pathogenic understanding of inflammatory airway disease (IAD) requires further investigation in many aspects, including how it differs from phenotypes in chronic obstructive pulmonary disease (COPD) [Barnes, 2008], as well as in children [Spycher, 2010]. Hence, a major challenge in the field of respiratory disease today is how to adapt the definition of asthma to new scientific developments. The verification of objective 'biotypes', in terms of the development of asthma and the patients in whom they are observed, is an important conceptual advance, provided better clinical management for each patient is achieved so that the relative uniqueness of each patient with asthma can be better understood, both by the physician and the patients themselves. However, in order to define 'phenotypes' specific to patients or subgroups of patients in addition to the specific pathogenic 'endotypes' that identify them (in other words, how asthma patients become ill), it is necessary to thoroughly identify their defining characteristics. They must therefore be measured and grouped biologically and clinically in a differentiated way, even if certain aspects of the illness are the same [Lotvall et al., 2011; Moore et al., 2010].

Today's objective biological measures and markers used to better understand these biotypes are the central focus of this chapter.

\section{Monitoring the airway and monitoring asthma in particular}

There are a number of methods available for identifying different aspects related to the natural evolution of IAD. The contribution of each aspect is determined by providing appropriate measures and robust parameters that meet consistent methodological determinants, such as the standardization of the method used, the availability of reference values, the reproducibility of findings, and above all the application of research findings to clinical practice and the global management of patients whose situation is well-defined as well as homogeneous patients or groups of subjects. Not all biological measures studied in recent years have managed to become routinely added as a parameter with clinical value in 
the management of patients. Furthermore, those used routinely provide specific and limited information only. Therefore, current research being conducted focuses more on the inflammatory aspects of the lung, rather than the classical or clinical function, because it is the central pathogenic mechanism of the disease in the airway [Fabbri et al., 2005]. Severity and control disease assessment requires a multidimensional practical approach including an inflammatory view, as was previously confirmed by some authors [Fitzpatrick et al. 2011a; Haldar et al., 2008].

Technological advancements brought about by modern molecular biology and innovative micron analysis technology applied to the study of inflammation and the pathways of oxidative, lipid, or nitric stress, for example, can allow for a better identification and definition of new parameters, inflammatory profiles, and biomarkers that are more sensitive and specific for predicting the state of progression of IAD, differences in poor outcomes, and the type of anti-inflammatory treatment best suited to manage a particular patient or patient group.

This section briefly discusses the most relevant parameters used in clinical practice for the monitoring of asthma, especially the most recent parameters that contribute greatly to the overall management of patients and other more promising parameters, from the perspective derived by direct measurement and monitoring of inflammatory activity.

\subsection{Global systems of measurement for airway disease}

From a clinical point of view, patients are typically monitored through the measurement of the symptoms present, questionnaires on the degree of control of the disease [Curtis et al., 1997] or the impact on quality of life related to health [Juniper et al., 2004], pathophysiological parameters such as the degree of bronchial obstruction [FEV ${ }_{1}$ or PEF] [Miller, 2005], and variability [Reddel, 2006] or the degree of bronchial hyper-reactivity, both specific and nonspecific [Anderson, 2008b, Cockcroft \& Davis 2006; Crapo et al., 2000; Sont et al., 1999; Sterk et al., 1993]. Each of these are more or less direct methods of measuring the clinical impact of inflammatory diseases of the airways, providing complementary information to diagnostic and therapeutic management [Fuhlbrigge, 2004; Gibson \& Powell, 2004; Taylor et al., 2008] and, to a lesser degree, clinical interpretation [Frey \& Suki, 2008]. They have become absolutely necessary and indispensable for the classification of the patient's and establishment of control disease. In terms of study, testing of the whole response of the total airway implies knowing several pathogenic mechanisms of disease [Bousquet et al., 2000; Leuppi et al., 2001]. Understanding how control of the severity or clinical evolution of the disease is developed retains some specific limitations that result in advantages and disadvantages. For example, the main advantage of studying bronchial hyper-responsiveness to histamine or methacholine challenge is the high negative predictive value of the test [Luks et al., 2010]. On the contrary, its presence and the severity observed indicate functional impairment of the airway. This may be interpretable in either a physiological (dysfunction, with or without an associated inflammatory basal profile) or pathological context (chronic inflammation, injury, mucosal or submucosal remodelling), which may or may not be modified by treatment once established [Hargreave et al., 1981; Rosi et al., 1999; Sont et al., 1999; van Essen-Zandvliet et al., 1994]. Recent advances in the clinical use of substances, such as adenosine or mannitol, provide additional data on the association between bronchial hyper-responsiveness, as measured by these indirect stimuli, and markers of inflammation [Polosa et al., 2000; Rutgers et al., 2000]. 
Other findings arising from the current radiological spectrum of diseases of the airway also provide useful data to study dynamic airway inflammation, expressed as the degree of trapped air and bronchial wall thickness [Gupta et al., 2010].

It is therefore possible to say that although the parameters and measurements discussed in this section can be applied to both asthma and COPD in order to achieve better clinical management, its meaning and clinical interpretation are often heterogeneous or variable depending on the patient, the therapy administered at the time of measurement, and the spectrum of IADs identified in the subject, both initially and over time [Avital et al., 1995; Dima et al., 2010]. Discrimination of all the spectrum of obstructive airway diseases is the goal to achieve at present time.

\subsection{Direct systems of injury and repair measurement in pulmonary biology}

The pathology of the airway has a clearly inflammatory pathophysiological basis, although the role this plays, both in the short term and in the long term, in the biological continuum of integrity, dysfunction, injury, and repair continues to undergo constant research. Traditionally, the gold standard in inflammatory activity has been to use various measurements and markers, both inflammatory and those of oxidative stress, obtained invasively by bronchial biopsy and bronchoalveolar lavage [Bergeron et al., 2007; Brasier et al., 2010; Hallstrand et al., 2011]. Although various parameters and histological patterns of inflammation have been identified with these techniques, many of them are shared by the anatomopathological spectrum of IAD. This causes ambiguity, both in the various pathogenic contexts in which pathophysiological interpretation is difficult and, consequently, non-pathognomonic situations in which discrimination regarding asthma or COPD occurs. Only some of these findings have demonstrated applicability to clinical care and a certain ability to differentiate or discriminate between the inflammatory pathogenic states of an underlying pathologic lesion, as in the study of bronchial remodelling [Sont et al., 1999; Sont et al., 2003], or the prevalence of the cellular profile of bronchial infiltration, as in the case of life-threatening asthma [Mauad et al., 2004; Mauad et al., 2008]. Furthermore, both techniques also have some significant limitations when carried out routinely. The first is that only one compartment of the airway is represented unless both procedures are done at the same time. The second limitation is the invasiveness of the procedure. This is an obstacle when routinely performed on the patient, despite the fact that these methods have been standardized and allow for a better visualization of the type of inflammation and anatomical injury caused by IAD in certain patients. They are also useful in studying the pathogenic mechanisms involved, as well as classifying and identifying the stage of disease [Fabbri et al., 2003; Fabbri et al., 2005; Moore et al., 2011], but the requirements of the procedure do not make them suitable for routine monitoring of the patient and are therefore generally reserved today for the systematic study of inflammation in pulmonary biology research.

The new semi-invasive methods, such as induced sputum, or non-invasive methods, such as the measurement of nitric oxide, condensation, or exhaled temperature, provide new and useful data directly from the airway that may be used in the classification of IADs and the management of patients [Popov, 2011]. Some markers derived from blood samples can also be used in assessing inflammatory disease and its systemic impact. These include eosinophil cationic proteins, as well as cationic peroxidase and leucotriens [Koh et al., 2007; Rabinovitch, 2007], but other novel systemic blood biomarkers are also promising [Verrills 
et al., 2011]. The most important contributions of non-invasive methods currently used to measure inflammation of the airway and the most promising research being carried out with new applied technologies in molecular biology and immunology are discussed below.

\subsubsection{Induced sputum}

This semi-invasive technique is used to obtain a representative sample of bronchial secretions in the airway. Some methodological variations in the induction procedure may produce samples from a more central or peripheral compartment of the airway, providing versatility in IAD screening in terms of both central and peripheral orientation. This is characterized as such because the differential inflammatory profile obtained is reproducible and can be correctly interpreted in a clinical context. However, this is not the case in the study of the various markers of inflammation and oxidative stress obtained from the supernatant, which have strict methodological considerations and limitations in the interpretation of results [Nicholas, 2009]. Bearing this in mind, induced sputum has become the gold standard non-invasive method for measuring bronchial cell inflammation and for certain soluble markers that are identifiable and of specific dilution [Bakakos, 2011; Djukanovic 2004]. The standardization of the method and procedure, adequate safeness of the technique, good toleration by the patient, ease of use, and the obtainment of reference values have made it an essential technique in the study of complex patients who require the characterization of the bronchial inflammatory pattern in order to be managed correctly [Djukanovic, 2002]. The current characterization of the endotypes and phenotypes of patients with inflammatory airway disease, based on inflammatory cell patterns [Balzar et al., 2011; Haldar et al., 2008], and the combination of different biomarkers, such as those derived from 'esputoma' [Gray et al., 2008; Nicholas, 2006] and oxidative stress [Louhelainen et al., 2008a; Louhelainen et al., 2008b], 15-lipoxygenase pathway [Chu, et al., 2002], gluthation oxidation [Fitzpatrick et al., 2011b] or genetics and protein identification [Baines et al., 2011; Hastie et al, 2010] make sputum an indisputable protagonist in the new definition of phenotypes, the classification of patients with asthma and COPD [Fabbri et al., 2003; Fatj et al., 2009; Louis et al., 2002; Wang et al., 2011], the therapeutic management of these patients, the prediction of therapeutic response [Green et al., 2002; Jayaram et al., 2006, Caramori et al., 2005], and the evaluation of efficacy in the most recent anti-inflammatory molecules [Haldar et al, 2009; Pavord et al. 2009, van Rensen et al. 2009]. Currently, new techniques in molecular biology may be applied to the study of sputum in order to study the expression shown in the cellular response of certain subtypes of cell lines, as found for example, by studying toll-like cell receptors or local innate immunity measured by flow cytometry [Lay et al, 2011], or those derived from cell cultures [Bettiol et al., 2002], the cellular response to markers of cell migration [Dent et al., 2004], or even those obtained from the analysis of proteomics traces or esputoma [Park \& Rim, 2011; Nicholas \& Djukanovic, 2009], as well as the genome [Baines et al., 2011; Bisgaard et al., 2011].

\subsubsection{The exhaled fraction determined singularly or in combination}

The use of exhaled markers capable of reflecting a clinically useful measurement of the inflammation and oxidative stress present in the airway currently involves bronchial nitric oxide (NO) as the main marker [Barnes et al., 2010]. This measurement is reproducible and the method has been standardized [ATS/ERS, 2005]. Because its concentration is dependent on the flow and the source of production, a compartmental model of alveolar or bronchial 
origin of exhaled nitric oxide has been developed in order to study of the origin of the alteration and the lung injury, situating it at a more central or peripheral level in the airway [Puckett et al., 2010]. This model allows the production variability within the spectrum of IAD and the anti-inflammatory modulation produced by the therapy administered to be studied in depth. While this method is certainly advantageous when carrying out clinical monitoring within a timeframe because of its non-invasivity, it may only be used in certain patients, i.e. those in whom the main source of NO has been identified as a clearly modifiable and dependent element of the course of inflammation with therapeutic antiinflammatory management, or for the screening of type of activated inflammation [Anderson et al., 2011]. The use of NO in the research of no homogeneously selected patients leads to a clinically confusing interpretation in terms of its identification and therefore must be considered limited or biased under these circumstances [Dweik et al., 2010]. In addition, certain methodological considerations conditioned by the design of NO research studies regarding the cut-off used to make a management decision must be taken into account during diagnosis and treatment, i.e. conditioning the patient management strategy based on the levels of NO [Gibson, 2009; Quaedvlieg et al., 2009; Schleich et al., 2009; Schneider et al., 2009].

Other exhaled markers of the bronchial airway, such as the detection of carbon monoxide and other volatile hydrocarbon compounds, products of lipid peroxidation, have also been studied [Antczak et al., 2011]. However, a definitive standardization of methods for immediate application in a clinical context has not been achieved. Similarly, the measurement of exhaled temperature increase at the start of breathing with regard to the reference point marked during the entire period of measurement of the increase is associated with the presence of active inflammation and airway remodelling [Paredi, 2005]. This also occurs with the measurement of bronchial blood flow, estimated by mass spectrometry using the Fick principle, and the calculation of the dilution of exhaled acetylene [the initial concentration inhaled is known]. Both methods may have their place in the spectrum of non-invasive monitoring of bronchial inflammation if the optimal exhaled flow is standardized methodologically for the purpose of measurement [Paredi \& Barnes, 2010].

The identification of different volatile compounds produced by oxidative stress, nitrosative stress, inflammation and metallic elements, and obtained from the exhaled condensate has also been possible through the use of chromatography and mass spectrometry [Corradi et al. 2007; Corradi et al, 2010]. Some of these compounds may be considered biomarkers in clinical practice [Baraldi et al., 2009 Kostikas et al., 2008; Loukides et al, 2011], such as pH determination [Kostikas et al., 2011; Antus et al, 2010]. However, it is necessary to simplify the instrumentation of the procedure for routine use in clinical practice. The standardization of methodology and applicability to clinical practice of other compounds under investigation as potential biomarkers has yet to be sufficiently achieved due, among other things, to certain limitations, such as contamination of condensate compounds of the mouth (especially if concomitant oral inflammation occurs), difficulty in calculating the optimal dilution of the selected parameter, or instability, volatility, and interaction of the mixture of soluble compounds that can take place during this process [Horvàth et al. 2005]. Comparisons with other biomarkers obtained and already standardized are needed to establish the utility of the different compounds of exhaled condensate, especially if 
performed one by one [Baraldi et al., 2009]. However, recent specific phenotypes of asthma patients, like aspirin intolerant asthmatics can be identified [Sanak et al, 2011].

Calculating the nasal exhaled fraction may be useful for the study and diagnosis of primary ciliary dyskinesia and is virtually abolished in this disease [Horváth et al., 2003]. On the contrary nasal NO levels are higher in rhinitis [Struben et al., 2006]

\subsubsection{The multiple molecular studies of biological lung samples, or systemic samples, significant to pulmonary disease}

Since the detection of a single marker of inflammation or oxidative stress does not identify a specific inflammatory disease of the airway as defined today, but rather proves the heterogeneity of inflammatory conditions and diseases of the airway, current research on biological markers focuses on a combination of identifying patterns of proteins and volatile compounds that can be identified by molecular marks or traces they contain. At the molecular level, many omic compounds (proteomic, metabolomic, genomic) may be identified. Within the field of respiratory medicine, these compounds will remain an enigma until the wealth of empirical molecular information is organized and interpreted, free of $a$ priori hypotheses, and the subsequent translation to clinical practice can be carried out. Such information would have the great advantage of producing a custom 'fingerprint' of inflammation during a specific time point in the evolution of the disease process in a particular patient. The correct interpretation of molecular information will allow the clinician to identify and predict the patient and disease biotypes (phenotype and endotype), the severity of the inflammatory process in progress, the clinical evolution, the type of treatment to be applied, the response to the therapy administered, and the prognosis for each individual patient [Crameri, 2005; Vijverberg et al., 2011]. The new molecular application technology based on bioinformatics, cluster analysis, and artificial intelligence algorithms that are being developed at present provide all this information for the purpose of prediction and interpretation at a biological level. This is useful in understanding the new biology of systems integration [Perpiñá, 2010; Scott et al., 2007; Thaler \& Hanson, 2005]. The following is a description of the research currently being conducted.

First, chromatography and mass spectrometry have been used to identify hundreds of volatile exhaled organic compounds originating from the metabolic pathways involved in pulmonary biology. However, their use as biomarkers with a clinical application is still under study [Freidrich, 2009]. Secondly, the addition of other specific technology for determining the spectrum of metabolites, proteins or organic compounds in different biological samples (cellular, fluid, or gas) in blood, sputum, or bronchoalveolar lavage, and developed on line, such as the application a multiple set of nanosensors (arrays) or the application of high-resolution nuclear magnetic resonance, has achieved rapid progress in identifying potential profiles and patterns of disease-specific biomarkers. For example, different patterns of compounds originating in breathing and exhaled breath evaluated by the so-called electronic nose identify molecules of different size, volume and dipole [Lewis, 2004]. These patterns have shown good sensitivity and discrimination capabilities for this combination and may be as helpful as those already described for the identification of certain odours, producing an odoriferous mark or smellprint. This would specifically identify the type of inflammation present and could be useful in the differential diagnosis of specific IADs [Dragonieri et al., 2007] in addition to the particular diagnostic and therapeutic strategies for each patient. 


\section{The future of targeted and individualized biological respiratory therapy}

The new concept of biotypes (endotypes and phenotypes) of IAD is transforming the definition of asthma to the point where it will soon be possible to obtain a more accurate simplification of what is understood today as asthma in order to better adapt to patient management and the clinical reality. However, the definition of asthma that currently exists is complex and will remain so, despite continuous modification and rehabilitation, given that although the heterogeneity of the IAD is better understood and the subtypes of the disease and patient subgroups are better classified, the multifactorial and dynamic aspects of the biological responses involved make applying reductionist criteria very difficult. It is therefore necessary to maintain a flexible and mentally versatile attitude that is as dynamic as biology itself. This attitude will facilitate the understanding of respiratory medicine of the future, which in turn will affect therapeutic management. This approach may be considered the cornerstone of individualized therapy for respiratory patients. It will aid in the progressive incorporation of biopharmaceuticals capable of regulating or altering inflammatory pathways, the remodelling process and the smooth muscle response. Both strategies are complementary and briefly commented.

First, the action and biological and immunological mechanisms will modulate the degree of response obtained at the molecular level and will result clinically in a very specific action. Being able to have these modulating biopharmaceuticals will be crucial and improve the quality of life for patients with IAD and asthma [Adock et al., 2008; Casale \& Stokes, 2008]. However, the availability of these drugs will lead to a major challenge at the clinical level that they will be reflected in trying to establish well-defined therapeutic indications to ensure safe, efficient, and cost-effective use. Some examples of modulating biopharmaceuticals in the context of eosinophilic inflammation that have been used in patients with poor control and greater severity of symptoms are those that interfere with the biological action of IgE, IL-5 or TNF $\alpha$. The attainment of adequate control and improvement of outcome in these patients is a sign of success in the development of new molecules, such as the monoclonal antibodies, mepolizumab, etarnercept or omalizumab [Holgate et al, 2011; Pavord et al., 2010; Pelaia et al., 2011]. Other biological modulating drugs acting at the neutrophilic, mast o lymphocite cells or other relevant molecules in the pathways and the inflammatory response, are being tested for the purpose of incorporation into the therapeutic arsenal available for IAD [Chung \& Marwick, 2010, Barnes, 2009]. Pharmacogenetics and understanding of innate immunty pathways are promising areas of research to discover determined mechanisms and specific molecules to reverse the altered inflammatory response [Caramori et al., 2004; Kanagaratham et al., 2011; Gupta \& Agrawal, 2010; Slager, 2010].

Second, the important thing to considering the therapy of releaving symptoms in the asthma clinic course is the understanding of the mechanical obstruction in the airways and the air-trapping compensatory consequence [Sorkness et al., 2008]. New long-acting smooth muscle relaxant molecules are been incorporated alone or in combination to the inhaler therapy [Cazzola et al., 2011; Chung et al., 2009; Kiyokawa et al., 2011; Postma et al., 2011], but recent knowing of the genetics of airway smooth muscle points out a new strategies to develop asthma targeted molecules [Hai, 2008]. Another specific therapy focus on smooth muscle of the airways, like bronchial thermoplasty, is still under evaluation [Thompson et al., 2011]. 


\section{Conclusion}

Inflammatory diseases of the airway, and asthma in particular, are complex and heterogenous, both in terms of the biological expression of inflammation they produce and in terms of the 'biotypes' (endotypes and phenotypes) that can be objectively translated from this condition. New information provided by new technology applied to modern molecular biology and immunology requires the current concept and definition of asthma to be modified and adapted. The attainment of this important progressive scientific knowledge can help to address how and why this condition occurs and may contribute to a better understanding of the classification of each asthma patient, the proper diagnosis of the type of asthma presented, the monitoring approach, the personalized treatment required, and the method to determine prognosis. A wide spectrum of biomarkers is currently being incorporated as clinically useful parameters. What remains is to gradually adapt them to comprehensive of multidimensional approaches and medical procedures, and establish the appropriate indications and clinical applications in respiratory disease.

\section{References}

[1] Adcock, IM.; Caramori, G. \& Chung, KF. (2008). New targets for drug development in asthma. Lancet. Vol. 372, No. 9643, (September 2008), pp.1073-1087, ISSN 0140-6736.

[2] American Thoracic Society; \& European Respiratory Society. (2005). ATS/ERS recommendations for standardized procedures for the online and offline measurement of exhaled lower respiratory nitric oxide and nasal nitric oxide, 2005. Am J Respir Crit Care Med. Vol.171, No 8, (April 2005), pp.912-930, ISSN 1073-449X.

[3] Anderson, GP. (2008a). Endotyping asthma: new insights into key pathogenic mechanisms in a complex, heterogenous disease. Lancet. Vol. 372, No. 9643, (September 2008), pp. 1107-1119, ISSN 0140-6736.

[4] Anderson, JT.; Zeng, M.; Li, Q.; Stapley, R.; Moore, DR 2nd.; Chenna, B.; Fineberg, N.; Zmijewski, J.; Eltoum, IE.; Siegal, GP.; Gaggar, A.; Barnes, S.; Velu, SE.; Thannickal, VJ.; Abraham, E.; Patel, RP.; Lancaster, JR Jr.; Chaplin, DD.; Dransfield, MT. \& Deshane, JS. (2011). Elevated levels of NO are localized to distal airways in asthma. Free Radic Biol Med. Vol. 50, No.11, (Juny 2011), pp.1679-1688, ISSN 0891-5849.

[5] Anderson, SD. (2008b). Provocative challenges to help diagnose and monitor asthma: exercise, methacholine, adenosine, and mannitol. Curr Opin Pulm Med. Vol. 14, No. 1, (January 2008), pp. 39-45, ISSN 1070-5287.

[6] Antczak, A.; Ciebiada, M.; Kharitonov, SA.; Gorski, P. \& Barnes, PJ. (2011). Inflammatory Markers: Exhaled Nitric Oxide and Carbon Monoxide During the Ovarian Cycle. Inflammation. May 18. [Epub ahead of print].

[7] Antus, B.; Barta, I.; Kullmann, T.; Lazar, Z.; Valyon, M.; Horvath, I. \& Csiszer, E. (2010). Assessment of exhaled breath condensate $\mathrm{pH}$ in exacerbations of asthma and chronic obstructive pulmonary disease: A longitudinal study. Am J Respir Crit Care Med. Vol.182, No.12, pp.1492-1497, ISSN 1073-449X.

[8] Avital, A.; Springer, C.; Bar-Yishay, E. \& Godfrey, S. (1995). Adenosine, methacholine, and exercise challenges in children with asthma or paediatric chronic obstructive pulmonary disease. Thorax. Vol. 50, No.5, (May 1995), pp.511-516, ISSN 0040-6376. 
[9] Baines, KJ.; Simpson, JL.; Wood, LG.; Scott, RJ. \& Gibson, PG. (2011). Transcriptional phenotypes of asthma defined by gene expression profiling of induced sputum samples. J Allergy Clin Immunol. Vol. 127. No.1, (January 2011), pp.153-160, ISSN 0091-6749.

[10] Bakakos, P.; Schleich, F.; Alchanatis, M. \& Louis, R. (2011). Induced sputum in asthma: from bench to bedside. Curr Med Chem. Vol. 18, No. 10, pp.1415-1422. ISSN 09298673.

[11] Balzar, S.; Fajt, ML.; Comhair, SA.; Erzurum, SC.; Bleecker, E.; Busse, WW.; Castro, M.; Gaston, B.; Israel, E.; Schwartz, LB.; Curran-Everett, D.; Moore, CG. \& Wenzel, SE. (2011). Mast cell phenotype, location, and activation in severe asthma: data from the severe asthma research program. Am J Respir Crit Care Med. Vol.183, Vol.3, pp.299-309, ISSN 1073-449X.

[12] Baraldi, E.; Carraro, S.; Giordano, G.; Reniero, F.; Perilongo, G. \& Zacchello, F. (2009). Metabolomics: moving towards personalized medicine. Ital J Pediatr. Vol. 35, No.1, (October 2009), p.30, ISSN 1720-8424.

[13] Barnes, PJ. (2008). Immunology of asthma and chronic obstructive pulmonary disease. Nat Rev Immunol. Vol. 8, No. 3, (March 2008), pp. 183-192, ISSN 1474-1733.

[14] Barnes, PJ. (2009). Histone deacetylase-2 and airway disease. Ther Adv Respir Dis. Vol.3, No.5, (October 2009), pp.235-243, ISSN 1753-4658.

[15] Barnes, PJ.; Dweik, RA.; Gelb, AF.; Gibson, PG.; George, SC.; Grasemann, H.; Pavord, ID.; Ratjen, F.; Silkoff, PE.; Taylor, DR. \& Zamel, N. (2010). Exhaled nitric oxide in pulmonary diseases: a comprehensive review. Chest. Vol. 138, No. 3, (September 2010), pp.682-692, ISSN 0012-3692.

[16] Bergeron, C.; Tulic, MK. \& Hamid, Q. (2007). Tools used to measure airway remodelling in research. Eur Respir J. Vol. 29, No.3, (March 2007), pp.596-604, ISSN 0903-1936.

[17] Bettiol, J.; Sele, J.; Henket, M.; Louis, E.; Malaise, M.; Bartsch, P. \& Louis, R. (2002). Cytokine production from sputum cells after allergenic challenge in IgE-mediated asthma. Allergy. Vol.57, No.12, (December 2002), pp.1145-1150, ISSN 0105-4538.

[18] Bisgaard, H.; Pipper, CB. \& Bønnelykke, K. (2011). Endotyping early childhood asthma by quantitative symptom assessment. J Allergy Clin Immunol. Vol. 127, No. 5, (May 2011), pp.1155-1164, ISSN 0091-6749.

[19] Bousquet, J.; Jeffery, PK.; Busse, WW.; Johnson, M. \& Vignola, AM. (2000). Asthma. From bronchoconstriction to airways inflammation and remodeling. Am J Respir Crit Care Med. Vol.161, No.5, (May 2000), pp.1720-1745, ISSN 1073-449X.

[20] Brasier, AR.; Victor, S.; Ju, H.; Busse, WW.; Curran-Everett, D.; Bleecker, E.; Castro, M.; Chung, KF.; Gaston, B.; Israel, E.; Wenzel, SE.; Erzurum, SC.; Jarjour, NN. \& Calhoun, WJ. (2010). Predicting intermediate phenotypes in asthma using bronchoalveolar lavage-derived cytokines. Clin Transl Sci. Vol. 3, No.4, (August 2010), pp.147-157, ISSN 1752-8054.

[21] British Thoracic Society Scottish Intercollegiate Guidelines Network. (2008) British guideline on the management of Asthma. Thorax. Vol.63, No. Suppl. 4, pp. iv1-121, ISSN 0040-6376. 
[22] Caramori, G.; Adcock, IM. \& Ito, K. (2004). Anti-inflammatory inhibitors of IkappaB kinase in asthma and COPD. Curr Opin Investig Drugs. Vol.5, No.11, (November 2004), pp.1141-1147, ISSN 1472-4472.

[23] Caramori, G.; Pandit, A. \& Papi, A. (2005). Is there a difference between chronic airway inflammation in chronic severe asthma and chronic obstructive pulmonary disease?. Curr Opin Allergy Clin Immunol. Vol. 5, No.1, (February 2005), pp.77-83. ISSN 1528-4050.

[24] Casale, TB, \& Stokes, JR. (2008). Immunomodulators for allergic respiratory disorders. J Allergy Clin Immunol. Vo.121. No. 2, (February 2008), pp. 288-296, ISSN 0091-6749.

[25] Cazzola, M.; Calzetta, L. \& Matera, MG. (2011). $\beta(2)$-adrenoceptor agonists: current and future direction. Br J Pharmacol. Vol.163, No.1, (May 2011) pp.4-17, ISSN 14765381.

[26] Chu, HW.; Balzar, S.; Westcott, JY.; Trudeau, JB.; Sun, Y.; Conrad, DJ. \& Wenzel, SE. (2002). Expression and activation of 15-lipoxygenase pathway in severe asthma: relationship to eosinophilic phenotype and collagen deposition. Clin Exp Allergy. Vol. 32, No 11, pp.1558-1565, ISSN 1365-2222.

[27] Chung, KF, \& Marwick, JA. (2010). Molecular mechanisms of oxidative stress in airways and lungs with reference to asthma and chronic obstructive pulmonary disease. Ann N Y Acad Sci. Vol. 1203, (August 2010), pp. 85-91, ISSN 0077-8923.

[28] Chung, KF.; Caramori, G. \& Adcock, IM. (2009). Inhaled corticosteroids as combination therapy with beta-adrenergic agonists in airways disease: present and future. Eur J Clin Pharmacol. Vol. 65, No.9, (Sepetember 2009), pp.853-871, ISSN 0031-6970.

[29] Cockcroft, DW. \& Davis, BE. (2006). Mechanisns of airway hyperresponsiveness. J Allergy Clin immunol. Vol. 118, No. 3 (Setember 2006), pp. 551-559, ISSN 0091-6749.

[30] Corradi, M.; Gergelova, P. \& Mutti, A. (2010). Use of exhaled breath condensate to investigate occupational lung diseases. Curr Opin Allergy Clin Immunol. Vol. 10, No. 2, (April 2010), pp.93-98, ISSN 1528-4050.

[31] Corradi, M.; Zinelli, C. \& Caffarelli, C. (2007). Exhaled breath biomarkers in asthmatic children. Inflamm Allergy Drug Targets. Vol. 6, No. 3, (Sepetember 2007), pp.150-159, ISSN 1871-5281.

[32] Crameri, R. (2005). The potential of proteomics and peptidomics fro allergy asnd asthma. Allergy. Vol. 60, No.10, (October 2005), pp. 1227-1237, ISSN 0105-4538.

[33] Crapo, RO.; Casaburi, R.; Coates, AL.; Enright, PL.; Hankinson, JL.; Irvin, CG.; MacIntyre, NR.; McKay, RT.; Wanger, JS.; Anderson, SD.; Cockcroft, DW.; Fish, JE. \& Sterk, PJ. (2000). Guidelines for methacoline and exercise challenge testing-1999. This official statement of the American Thoracic Society was adopted by the ATS Board of Directors, July 1999. Am J Respir Cri Care Med. Vol.161, No.1, (January 2000), pp. 309-329, ISSN 1073-449X.

[34] Curtis, JR.; Martin, DP. \& Martin, TR. (1997). Patient-assessed Health Outcomes in Chronic Lung Disease. Am J Respir Crit Care Med. Vol. 156, No. 4 pt1, (October 1997), pp.1032-1039, ISSN 1073-449X.

[35] Dent, G.; Hadjicharalambous, C.; Yoshikawa, T.; Handy, RL.; Powell, J.; Anderson, IK.; Louis, R.; Davies, DE. \& Djukanovic, R. (2004). Contribution of eotaxin-1 to 
eosinophil chemotactic activity of moderate and severe asthmatic sputum. Am J Respir Crit Care Med. Vol. 169, No.10, (May 2004), pp.1110-1117, ISSN 1073-449X.

[36] Dima, E.; Rovina, N.; Gerassimou, C.; Roussos, C. \& Gratziou, C. (2010). Pulmonary function tests, sputum induction, and bronchial provocation tests: diagnostic tools in the challenge of distinguishing asthma and COPD phenotypes in clinical practice. Int J Chron Obstruct Pulmon Dis. Vol. 5, (September 2010), pp.287-296, ISSN 1176-9106.

[37] Djukanovi,c R.; Sterk, PJ.; Fahy, JC. \& Hargreave, FE. (2002). Standardised methodology of sputum induction and processing. Eur Respir J. Vol. 20, No. suppl 37, (September 2002), pp. 1s-55s. ISSN 0903-1936.

[38] Djukanovic, R. \& Sterk, PJ. (2004). An atlas of induced sputum: an aid for research and diagnosis. The Partenon Publishing Group, ed. ISBN 1842140051. London.

[39] Dragonieri, S.; Schot, R.; Mertens, BJ.; Le Cessie, S.; Gauw, SA.; Spanevello, A.; Resta, O.; Willard, NP.; Vink, TJ.; Rabe, KF.; Bel, EH. \& Sterk, PJ. (2007). An electronic nose in the discrimination of patients with asthma and controls. J Allergy Clin Immunol. Vol. 120, No.4, (October 2007), pp.856-862, ISSN 0091-6749.

[40] Dweik, RA.; Sorkness, RL.; Wenzel, S.; Hammel, J.; Curran-Everett, D.; Comhair, SA.; Bleecker, E.; Busse, W.; Calhoun, WJ.; Castro, M.; Chung, KF.; Israel, E.; Jarjour, N.; Moore, W.; Peters, S.; Teague, G.; Gaston, B.; Erzurum, SC. \& National Heart, Lung, and Blood Institute Severe Asthma Research Program. (2010). Use of exhaled nitric oxide measurement to identify a reactive, at-risk phenotype among patients with asthma. Am J Respir Crit Care Med. Vol.181, No.10, (May 2010), pp.1033-1341. ISSN 1073-449X.

[41] Fabbri, L.; Peters, SP.; Pavord, I.; Wenzel, SE.; Lazarus, SC.; Macnee, W.; Lemaire, F. \& Abraham, E. (2005). Allergic rhinitis, asthma, airway biology, and chronic obstructive pulmonary disease in AJRCCM in 2004. Am J Respir Crit Care Med. Vol.171, No.7, (April 2005), pp.686-698, ISSN 1073-449X.

[42] Fabbri, LM.; Romagnoli, M.; Corbetta, L.; Casoni, G.; Busljetic, K.; Turato, G.; Ligabue, G.; Ciaccia, A.; Saetta, M. \& Papi, A. (2003). Differences in airway inflammation in patients with fixed airflow obstruction due to asthma or chronic obstructive pulmonary disease. Am J Respir Crit Care Med. Vol.167, No. 3, (Frebruary 2003), pp.418-424, ISSN 1073-449X.

[43] Fajt, ML. \& Wenzel, SE. (2009). Asthma phenotypes in adults and clinical implications. Expert Rev Respir Med. Vol.3, No. 6, (December 2009), pp.607-625, ISSN 1747-6348.

[44] Fitzpatrick, AM, Teague, WG, Meyers, DA, Peters, SP, Li, X, Li, H, Wenzel, SE, Aujla, S, Castro, M, Bacharier, LB, Gaston, BM, Bleecker, ER, Moore, WC; National Institutes of Health/National Heart, Lung, and Blood Institute Severe Asthma Research Program. Heterogeneity of severe asthma in childhood: confirmation by cluster analysis of children in the National Institutes of Health/National Heart, Lung, and Blood Institute Severe Asthma Research Program. (2011a). J Allergy Clin Immunol. Vol.127, No.2, (Febreuary 2011), pp.382-389. ISSN 0091-6749.

[45] Fitzpatrick, AM.; Teague, WG.; Burwell, L.; Brown, MS.; Brown, LA; \& NIH/NHLBI Severe Asthma Research Program. (2011b). Glutathione oxidation is associated 
with airway macrophage functional impairment in children with severe asthma. Pediatr Res. Vol. 69, No.2, (February 2011), pp.154-159. ISSN 0031-3998.

[46] Frey, U. \& Suky, B. (2008). Complexity of chronic asthma and chronic obstructive pulmonary disease: implications for risk assessment, and disease progression and control. Lancet. Vol. 372, No. 9643, (September 2008), pp.1088-1099, ISSN 0140-6736.

[47] Friedrich, MJ. (2009). Scientists seek to sniff out diseases: electronic "noses" may someday be diagnostic tools. JAMA. Vol. 301, No.6, (February 2009), pp.585-586, ISSN 0098-7484.

[48] Fuhlbrigge, AL. (2004). Asthma severity and asthma control: symptoms, pulmonary function, and inflammatory markers. Curr Opin Pulm Med. Vol. 10, No. 1, (January 2004), pp. 1-6, ISSN 1070-5287.

[49] Gibson, PG. \& Powell, H. (2004) Written actions plans for asthma: an evidence-based review of the key components. Thorax. Vol. 59, No. 2, (February 2004), pp. 94-99, ISSN 0040-6376.

[50] Gibson, PG. (2009). Using fractional exhaled nitric oxide to guide asthma therapy: design and methodological issues for ASthma TReatment ALgorithm studies. Clin Exp Allergy. Vol.39, No.4, (April 2009), pp.478-490, ISSN 1365-2222.

[51] Global Initiative for Asthma. Global strategy for asthma management and prevention. Available at http//www.ginasthma.org [accessed 8 March 2009].

[52] Gray, RD.; MacGregor, G.; Noble, D.; Imrie, M.; Dewar, M.; Boyd, AC.; Innes, JA.; Porteous, DJ. \& Greening, AP. (2008). Sputum proteomics in inflammatory and suppurative respiratory diseases. Am J Respir Crit Care Med. Vol. 178, No. 5, (September 2008), pp.444-452, ISSN 1073-449X.

[53] Green, RH.; Brightling, CE.; McKenna, S.; Hargadon, B.; Parker, D.; Bradding, P.; Wardlaw, AJ. \& Pavord, ID. (2002). Asthma exacerbations and sputum eosinophil counts: a randomised controlled trial. Lancet. Vol. 360, No. 9347, (November 2002), pp.1715-1721, ISSN 0140-6736.

[54] Gupta, GK. \& Agrawal, DK. (2010). CpG oligodeoxynucleotides as TLR9 agonists: therapeutic application in allergy and asthma. BioDrugs. Vol. 24, No. 4, (August 2010), pp.225-35, ISSN 1173-8804.

[55] Gupta, S.; Siddiqui, S.; Haldar, P.; Entwisle, JJ.; Mawby, D.; Wardlaw, AJ.; Bradding, P.; Pavord, ID.; Green, RH. \& Brightling, CE. (2010). Quantitative analysis of highresolution computed tomography scans in severe asthma subphenotypes. Thorax. Vol. 65, No.9, (September 2010), pp.775-781, ISSN 0040-6376.

[56] Hai, CM. Mechanistic systems biology of inflammatory gene expression in airway smooth muscle as tool for asthma drug development. (2008). Curr Drug Discov Technol. Vol.5, No.4, (December 2008), pp.279-288, ISSN 1570-1638.

[57] Haldar, P.; Brightling, CE.; Hargadon, B.; Gupta, S.; Monteiro, W.; Sousa, A.; Marshall, RP.; Bradding, P.; Green, RH.; Wardlaw, AJ. \& Pavord, ID. (2009). Mepolizumab and exacerbations of refractory eosinophilic asthma. N Engl J Med. Vol. 360, No. 10, (March 2009), pp. 973-984. Erratum in: N Engl J Med Vol. 364, No.6, (February 2011), p.588, ISSN 1533-4406. 
[58] Haldar, P.; Pavord, ID.; Shaw, DE.; Berry, MA.; Thomas, M.; Brightling, CE.; Wardlaw, AJ. \& Green, RH. (2008). Cluster analysis and clinical asthma phenotypes. Am J Respir Crit Care Med. Vol. 178, No.3, (August 2008), pp.218-224, ISSN 1073-449X.

[59] Hallstrand, TS.; Lai, Y.; Ni, Z.; Oslund, RC.; Henderson, WR Jr.; Gelb, MH. \& Wenzel, SE. (2011). Relationship between levels of secreted phospholipase A[2] groups IIA and $X$ in the airways and asthma severity. Clin Exp Allergy. Vol. 41, No. 6, (June 2011), pp.801-810, ISSN 1365-2222.

[60] Hargreave, FE. \& Nair, P. (2009). The definition and diagnosis of asthma. Clin Exp Allergy, Vol. 39, No.11, (November 2009), pp.1652-1658, ISSN 1365-2222.

[61] Hargreave, FE.; Ryan, G.; Thomson, NC.; O’Byrne, PM.; Latimer, K.; Juniper, EF \& Dolovich, J. (1981). Bronchial responsiveness to histamine or methacholine in asthma: measurement and clinical significance. J Allergy Clin Immunol. Vol. 68, No. 5, (November 1981), pp.347-355, ISSN 0091-6749.

[62] Hastie, AT.; Moore, WC.; Meyers, DA.; Vestal, PL.; Li, H.; Peters, SP.; Bleecker, ER. \& National Heart, Lung, and Blood Institute Severe Asthma Research Program. Analyses of asthma severity phenotypes and inflammatory proteins in subjects stratified by sputum granulocytes. (2010). J Allergy Clin Immunol. Vol. 125, No. 5, (May 2010), pp:1028-1036, ISSN 0091-6749.

[63] Holgate, ST. \& Polosa, R. (2006). The mechanisms, diagnosis, and management of severe asthma in adults. Lancet. Vol. 368, No. 9537, (August 2006), pp.780-93, ISSN 0140-6736.

[64] Holgate, ST.; Noonan, M.; Chanez, P.; Busse, W.; Dupont, L.; Pavord, I.; Hakulinen, A.; Paolozzi, L.; Wajdula, J.; Zang, C.; Nelson, H. \& Raible, D. (2011). Efficacy and safety of etanercept in moderate-to-severe asthma: a randomised, controlled trial. Eur Respir J. Vol. 37, No. 6, (Juny 2011), pp.1352-1359, ISSN 0903-1936.

[65] Horváth, I.; Hunt, J.; Barnes, PJ.; Alving, K.; Antczak, A.; Baraldi, E.; Becher, G.; van Beurden, WJ.; Corradi, M.; Dekhuijzen, R.; Dweik, RA.; Dwyer, T.; Effros, R.; Erzurum, S.; Gaston, B.; Gessner, C.; Greening, A.; Ho, LP.; Hohlfeld, J.; Jöbsis, Q.; Laskowski, D.; Loukides, S.; Marlin, D.; Montuschi, P.; Olin, AC.; Redington, AE.; Reinhold, P.; van Rensen, EL.; Rubinstein, I.; Silkoff, P.; Toren, K.; Vass, G.; Vogelberg, C.; Wirtz, H. \& ATS/ERS Task Force on Exhaled Breath Condensate. (2005). Exhaled breath condensate: methodological recommendations and unresolved questions. Eur Respir J. Vol.26, No.3, (September 2005), pp. 523-548, ISSN 0903-1936.

[66] Horváth, I.; Loukides, S.; Wodehouse, T.; Csiszér, E.; Cole, PJ.; Kharitonov, SA. \& Barnes, PJ. (2003). Comparison of exhaled and nasal nitric oxide and exhaled carbon monoxide levels in bronchiectatic patients with and without primary ciliary dyskinesia. Thorax. Vol. 58, No.1, (January 2003), pp.68-72. Erratum in: (2004) Thorax. Vol. 59, No.6, p.543, ISSN 0040-6376.

[67] Jayaram, L.; Pizzichini, MM.; Cook, RJ.; Boulet, LP.; Lemière, C.; Pizzichini, E.; Cartier, A.; Hussack, P.; Goldsmith, CH.; Laviolette, M.; Parameswaran, K. \& Hargreave, FE. (2006). Determining asthma treatment by monitoring sputum cell counts: effect on exacerbations. Eur Respir J. Vol. 27, No.3, (March 2006), pp.483-494, ISSN 09031936. 
[68] Juniper, EF.; Wisniewski, ME.; Cox, FM.; Emmett, AH.; Nielsen, KE. \& O’Byrne, PM. (2004). Relationship between quality of life and clinical status in asthma: a factor analysis. Eur Respir J. Vol. 23, No. 2, (February 2004), pp.287-291, ISSN 0903-1936.

[69] Kanagaratham, C.; Camateros, P.; Flaczyk, A. \& Radzioch, D. (2011). Polymorphisms in TOLL-like receptor genes and their roles in allergic asthma and atopy. Recent Pat Inflamm Allergy Drug Discov. Vol.5, No.1, pp.45-56, ISSN 1872-213X.

[70] Kiyokawa, H.; Matsumoto, H.; Nakaji, H.; Niimi, A, Ito, I.; Ono, K.; Takeda, T.; Oguma, T.; Otsuka, K. \& Mishima, M. (2011). Centrilobular Opacities in the Asthmatic Lung Successfully Treated with Inhaled Ciclesonide and Tiotropium: With Assessment of Alveolar Nitric Oxide Levels. Allergol Int. February 25. [Epub ahead of print], ISSN 1323-8930.

[71] Koh, G C-H.; Shek, L P-C.; Goh, D Y-T.; Van Bever, H. \& Koh, D S-Q. (2007). Eosinophil cationic protein: is it useful in asthma?. A systematic review. Respir Med. Vol. 101, No. 4, (April 2007), pp.696-705, ISSN 0954-6111.

[72] Kostikas, K.; Koutsokera, A.; Papiris, S.; Gourgoulianis, KI. \& Loukides, S. (2008). Exhaled breath condensate in patients with asthma: implications for application in clinical practice. Clin Exp Allergy. Vol. 38, No.4, (April 2008), pp.557-565, ISSN 13652222.

[73] Kostikas, K.; Papaioannou, AI.; Tanou, K.; Giouleka, P.; Koutsokera, A.; Minas, M.; Papiris, S.; Gourgoulianis, KI.; Taylor, DR.\& Loukides, S. (2011). Exhaled NO and exhaled breath condensate $\mathrm{pH}$ in the evaluation of asthma control. Respir Med. Vol.105, No.4, (April 2011), pp.526-532, ISSN 0954-6111.

[74] Lay, JC.; Peden, DB. \& Alexis, NE. (2011). Flow cytometry of sputum: assessing inflammation and immune response elements in the bronchial airways. Inhal Toxicol. Vol. 23, No. 7, (Juny 2011), pp.392-406, ISSN 0895-8378.

[75] Leuppi, JD.; Salome, CM.; Jenkins, CR.; Koskela, H.; Brannan, JD.; Anderson, SD.; Andersson, M.; Chan, HK. \& Woolcock, AJ. (2001). Markers of airway inflammation and airway hyperresponsiveness in patients with well-controlled asthma. Eur Respir J. Vol.18, (No.3, Sepetember 2001), pp.444-450, ISSN 0903-1936.

[76] Lewis, NS. (2004). Comparisons between mammalian and artificial olfaction based on arrays of carbon black-polymer composite vapor detectors. Acc Chem Res. Vol. 37, No.9, (September 2004), pp.663-672, ISSN 1520-4898.

[77] Lötvall, J.; Akdis, CA.; Bacharier, LB.; Bjermer, L.; Casale, TB.; Custovic, A.; Lemanske, RF Jr.; Wardlaw, AJ.; Wenzel, SE. \& Greenberger, PA. Asthma endotypes: a new approach to classification of disease entities within the asthma syndrome. (2011). J Allergy Clin Immunol. Vol.127, No.2, (February 2011), pp.355-360, ISSN 0091-6749.

[78] Louhelainen, N.; Myllärniemi, M.; Rahman, I. \& Kinnula, VL. Airway biomarkers of the oxidant burden in asthma and chronic obstructive pulmonary disease: current and future perspectives. (2008a). Int J Chron Obstruct Pulmon Dis. Vol. 3, No. 4, Pp. 585-603, ISSN 1176-9106.

[79] Louhelainen, N.; Rytilä, P.; Obase, Y.; Mäkelä, M.; Haahtela, T.; Kinnula, VL. \& Pelkonen, A. (2008b). The value of sputum 8-isoprostane in detecting oxidative stress in mild asthma. J Asthma. Vol. 45, No.2, (March 2008), pp.149-154, ISSN 15324303. 
[80] Louis, RE.; Cataldo, D.; Buckley, MG.; Sele, J.; Henket, M.; Lau, LC.; Bartsch, P.; Walls, AF. \& Djukanovic, R. (2002). Evidence of mast-cell activation in a subset of patients with eosinophilic chronic obstructive pulmonary disease. Eur Respir J. Vol. 20, No.2, (August 2002), pp.325-331, ISSN 0903-1936.

[81] Loukides S.; Kontogianni K.; Hillas G.\& Horvath I. (2011). Exhaled breath condensate in asthma: from bench to bedside. Curr Med Chem. Vol.18, No.10, pp.1432-1443, ISSN 1568-0118.

[82] Luks, VP.; Vandemheen, KL. \& Aaron, SD. (2010). Confirmation of asthma in an era of overdiagnosis. Eur Respir J. Vol.36, No. 2, (August 2010), pp.255-260, ISSN 09031936.

[83] Mauad, T.; Ferreira, DS.; Costa, MB.; Araujo, BB.; Silva, LF.; Martins, MA.; Wenzel, SE. \& Dolhnikoff, M. (2008). Characterization of autopsy-proven fatal asthma patients in São Paulo, Brazil. Rev Panam Salud Publica. Vol. 23, No.6, (June 2008), pp.418-423, 1020-4989.

[84] Mauad, T.; Silva, LF.; Santos, MA.; Grinberg, L.; Bernardi, FD.; Martins, MA.; Saldiva, PH. \& Dolhnikoff, M. (2004). Abnormal alveolar attachments with decreased elastic fiber content in distal lung in fatal asthma. Am J Respir Crit Care Med. Vol.170, No.8, (October 2004), pp.857-862, ISSN 1073-449X.

[85] Miller, MR.; Hankinson, J.; Brusasco, V.; Burgos, F.; Casaburi, R.; Coates, A.; Crapo, R.; Enright, P.; van der Grinten, CP.; Gustafsson, P.; Jensen, R.; Johnson, DC.; MacIntyre, N.; McKay, R.; Navajas, D.; Pedersen, OF.; Pellegrino, R.; Viegi, G.; Wanger, J. \& ATS/ERS Task Force. Series "Standardisation of spirometry. ATS/ERS task force, standardization of lung function testing". (2005). Eur Respir J. Vol. 26, No. 2, (August 2005), pp. 319-338, ISSN 0903-1936.

[86] Moore, WC.; Evans, MD.; Bleecker, ER.; Busse, WW.; Calhoun, WJ.; Castro, M.; Fan Chung, K.; Erzurum, SC.; Curran-Everett, D.; Dweik, RA.; Gaston, B.; Hew, M.; Israel, E.; Mayse, ML.; Pascual, RM.; Peters, SP.; Silveira, L.; Wenzel, SE. \& Jarjour, NN; for the National Heart, Lung, and Blood Institute's Severe Asthma Research Program. Safety of investigative bronchoscopy in the Severe Asthma Research Program. (2011). J Allergy Clin Immunol. Apr 13. [Epub ahead of print].

[87] Moore, WC.; Meyers, DA.; Wenzel, SE.; Teague, WG.; Li, H.; Li, X.; D'Agostino, R Jr.; Castro, M.; Curran-Everett, D.; Fitzpatrick, AM.; Gaston, B.; Jarjour, NN.; Sorkness, R.; Calhoun, WJ.; Chung, KF.; Comhair, SA.; Dweik, RA.; Israel, E.; Peters, SP.; Busse, WW.; Erzurum, SC.; Bleecker, ER. \& The National Heart, Lung, and Blood Institute's Severe Asthma Research Program. Identification of asthma phenotypes using cluster analysis in the Severe Asthma Research Program. (2010). Am J Respir Crit Care Med. Vol.181, No.4, (February 2010), pp.315-323, ISSN 1073-449X.

[88] Nicholas, B. \& Djukanovic, R. (2009). Induced sputum: a window to lung pathology. Biochem Soc. Trans. Vol. 37, No Pt4, (August 2009), pp.868-872, ISSN 0300-5127. 
[89] Nicholas, B.; Skipp, P.; Mould, R.; Rennard, S.; Davies, DE.; O'Connor, CD. \& Djukanović, R. (2006). Shotgun proteomic analysis of human-induced sputum. Proteomics. Vol. 6, No.15, (August 2006), pp.4390-4401, ISSN 1615-9853.

[90] Paredi, P. \& Barnes, PJ. (2009). The airway vasculature: recent advances and clinical implications. Thorax. Vol. 64, No. 5, (May 2009), pp.444-450, ISSN 0040-6376.

[91] Paredi, P.; Kharitonov, SA. \& Barnes, PJ. (2005). Correlation of exhaled breath temperature with bronchial blood flow in asthma. Respir Res. Vol.6, (February 2005), p.15, ISSN 1465-993X.

[92] Park, CS. \& Rhim, T. (2011). Application of proteomics in asthma research. Expert Rev Proteomics. Vol. 8, No. 2, (April 2011), pp.221-230, ISSN 1478-9450.

[93] Pavord, ID.; Haldar, P.; Bradding, P. \& Wardlaw, AJ. (2010). Mepolizumab in refractory eosinophilic asthma. Thorax. Vol. 65, No.4, (April 2010), p. 370, ISSN 0040-6376.

[94] Pavord, ID.; Jeffery, PK.; Qiu, Y.; Zhu, J.; Parker, D.; Carlsheimer, A.; Naya, I. \& Barnes, NC. (2009). Airway inflammation in patients with asthma with high-fixed or lowfixed plus as-needed budesonide/formoterol. J Allergy Clin Immunol. Vol.123, No. 5, pp.1083-1089, ISSN 0091-6749.

[95] Pelaia, G.; Gallelli, L.; Renda, T.; Romeo, P.; Busceti, MT.; Grembiale, LD.; Maselli, R.; Marisco, SA. \& Vatrella, A. (2011). Update on optimal use of omalizumab in management of asthma. J Asthma and Allergy. Vol.4, pp.49-59 ISSN 1178-6965.

[96] Perpiñá Tordera, M. (2010). Why do we look at asthma through the keyhole?. Arch Bronconeumol. Vol. 46, No. 8, (Augus 2010), pp.433-438, ISSN 0300-2896.

[97] Polosa, R.; Ciamarra, I.; Mangano, G.; Prosperini, G.; Pistorio, MP.; Vancheri, C. \& Crimi, N. (2000). Bronchial hyperresponsiveness and airway inflammation markers in nonasthmatics with allergic rhinitis. Eur Respir J. Vol.15, No.1, (January 2000), pp.30-35, ISSN 0903-1936.

[98] Popov, TA. Human exhaled breath analysis. (2011). Ann Allergy Asthma Immunol. Vol.106, No.6, (June 2011), pp.451-456, ISSN 1081-1206.

[99] Postma, DS.; O'Byrne, PM. \& Pedersen, S. (2011). Comparison of the effect of low-dose ciclesonide and fixed-dose fluticasone propionate and salmeterol combination on long-term asthma control. Chest. Vol.139, No.2, (February 2011), pp.311-318, ISSN 0012-3692.

[100] Puckett, JL.; Taylor, RW.; Leu, SY.; Guijon, OL.; Aledia, AS.; Galant, SP. \& George, SC. (2010). Clinical patterns in asthma based on proximal and distal airway nitric oxide categories. Respir Res. Vol. 11, (April 2010), p.47, ISSN 1465-993X.

[101] Quaedvlieg, V.; Sele, J.; Henket, M. \& Louis, R. (2009). Association between asthma control and bronchial hyperresponsiveness and airways inflammation: a crosssectional study in daily practice. Clin Exp Allergy. Vol. 39, No. 12, (December 2009), pp.1822-1829, ISSN 1365-2222.

[102] Rabinovitch, N. (2007). Urinary leukotriene E4. Immunol Allergy Clin N Am. Vol. 27. No. 6, (June 2007), pp. 451-464, ISSN 0889-8561.

[103] Reddel, HK. Peak flow monitoring in clinical practice and clinical asthma trials. (2006). Curr Opin Pulm Med. Vol. 12, No. 1, (January 2006), pp. 75-81, ISSN 1070-5287. 
[104] Rosi, E.; Ronchi, MC.; Grazzini, M.; Duranti, R. \& Scano, G. (1999). Sputum analysis, bronchial hyperresponsiveness, and airway function in asthma: results of a factor analtysis. J Allergy Clin Immunol. Vol. 103, No. 2 pt1, (February), pp.232-237, ISSN 0091-6749.

[105] Rutgers, SR.; Timens, W.; Tzanakis, N.; Kauffman, HF.; van der Mark, TW.; Koëter, GH. \& Postma, DS. (2000). Airway inflammation and hyperresponsiveness to adenosine 5'-monophosphate in chronic obstructive pulmonary disease. Clin Exp Allergy. Vol.30, No.5, (May 2000), pp.657-662, ISSN 1365-2222.

[106] Sanak, M.; Gielicz, A.; Bochenek, G.; Kaszuba, M.; Niżankowska-Mogilnicka, E. \& Szczeklik, A. (2011). Targeted eicosanoid lipidomics of exhaled breath condensate provide a distinct pattern in the aspirin-intolerant asthma phenotype. J Allergy Clin Immunol. Vol. 127, No.5, (May 2011), pp.1141-1147, ISSN 0091-6749.

[107] Schleich, FN.; Seidel, L.; Sele, J.; Manise, M.; Quaedvlieg, V.; Michils, A. \& Louis, R. (2010). Exhaled nitric oxide thresholds associated with a sputum eosinophil count $\geq 3 \%$ in a cohort of unselected patients with asthma. Thorax. Vol. 65, No.12, (December 2010), pp.1039-1044, ISSN 0040-6376.

[108] Schneider, A.; Tilemann, L.; Schermer, T.; Gindner, L.; Laux, G.; Szecsenyi, J. \& Meyer, FJ. (2009). Diagnosing asthma in general practice with portable exhaled nitric oxide measurement--results of a prospective diagnostic study: FENO $<$ or $=16 \mathrm{ppb}$ better than FENO $<$ or $=12 \mathrm{ppb}$ to rule out mild and moderate to severe asthma. Respir Res. Vol. 10, p.15. Erratum in (2009). Respir Res. Vol.10, (March 2009), p. 64, ISSN 1465-993X.

[109] Scott, SM.; James, D. \& Ali, Z. (2007). Data analysis for electronic nose systems. Microchim Acta. Vol. 156, pp. 183-207, ISSN 0026-3672.

[110] Slager, RE.; Hawkins, GA.; Ampleford, EJ.; Bowden, A.; Stevens, LE.; Morton, MT.; Tomkinson, A.; Wenzel, SE.; Longphre, M.; Bleecker, ER. \& Meyers, DA. (2010). IL4 receptor a polymorphisms are predictors of a pharmacogenetic response to a novel IL-4/IL-13 antagonist. J Allergy Clin Immunol. Vol.126, No.4, (October 2010), pp.875-878, ISSN 0091-6749.

[111] Sont, JK.; De Boer, WI.; van Schadewijk, WA.; Grünberg, K.; van Krieken, JH.; Hiemstra, PS.; Sterk, PJ. \& Asthma Management Project University of Leiden Study Group. (2003). Fully automated assessment of inflammatory cell counts and cytokine expression in bronchial tissue. Am J Respir Crit Care Med. Vol.167, No.11, (June 2003), pp.1496-1503, ISSN 1073-449X.

[112] Sont, JK.; Willems, LN.; Bel, EH.; van Krieken, JH.; Vandenbroucke, JP. \& Sterk PJ. (1999). Clinical control and histopathologic outcome of asthma when using airway hyperresponsiveness as an additional guide to long-term treatment. The AMPUL Study Group. Am J Respir Crit Care Med. Vol. 159, No. 4 pt 1, (April 1999), pp. 10431051, ISSN 1073-449X.

[113] Sorkness, RL.; Bleecker, ER.; Busse, WW.; Calhoun, WJ.; Castro, M.; Chung, KF.; Curran-Everett, D.; Erzurum, SC.; Gaston, BM.; Israel, E.; Jarjour, NN.; Moore, WC.; Peters, SP.; Teague, WG.; Wenzel, SE. \& National Heart, Lung, and Blood Institute Severe Asthma Research Program. (2008). Lung function in adults with stable but severe asthma: air trapping and incomplete reversal of obstruction with 
bronchodilation. J Appl Physiol. Vol.104, No.2, (February 2008), pp.394-403, ISSN 8750-7587.

[114] Spycher, BD.; Silverman, M. \& Kuehni, CE. (2010). Phenotypes of childhood asthma: are they real?. Clin Exp Allergy. Vol. 40, No.8, (August 2010), pp.1130-1141, ISSN 1365-2222.

[115] Sterk, PJ.; Fabbri, LM.; Quanjer, PH.; Cockcroft, DW.; O’Byrne, PM.; Anderson, SD.; Juniper, EF. \& Malo, JL. (1993). Airway responsiveness. Standardized challenge testing with pharmacological, physical and sensitizing stimuli in adults. Report Working Party Standardization of Lung Function Tests, European Community for Steel and Coal. Official Statement of the European Respiratory Society. Eur Respir J Suppl. Vol. 16, (March 1993), pp.53-83, ISSN 0106-4347.

[116] Struben, VM.; Wieringa, MH.; Feenstra, L. \& de Jongste, JC. (2006). Nasal nitric oxide and nasal allergy. Allergy. Vol. 61, No. 6, pp.665-670, ISSN 0105-4538.

[117] Taylor, DR.; Bateman, ED.; Boulet, LP.; Boushey, HA.; Busse, WW.; Casale, TB.; Chanez, P.; Enright, PL.; Gibson, PG.; de Jongste, JC.; Kerstjens, HA.; Lazarus, SC.; Levy, ML.; O'Byrne, PM.; Partridge, MR.; Pavord, ID.; Sears, MR.; Sterk, PJ.; Stoloff, SW.; Szefler, SJ.; Sullivan, SD.; Thomas, MD.; Wenzel, SE. \& Reddel, HK. (2008). A new perspective on concepts of asthma severity and control. Eur Respir J. Vol. 32, No. 3, (September 2008), pp.545-554, ISSN 0903-1936.

[118]Thaler, ER. \& Hanson, CW. (2005). Medical applications of electronic nose technology. Exert Rev Med Devices. Vol. 2, No. 5, (September 2005), pp. 559-566, ISSN 1743-4440.

[119] Thomson, NC.; Rubin, AS.; Niven, RM.; Corris, PA.; Siersted, HC.; Olivenstein, R.; Pavord, ID.; McCormack, D.; Laviolette, M.; Shargil,1 NS.; Cox, G. \& AIR Trial Study Group. (2011). Long-term (5 year) safety of bronchial thermoplasty: Asthma Intervention Research (AIR) trial. BMC Pulm Med. Vol.11, (February 2011), p.8, ISSN 1471-2466.

[120]van Essen-Zandvliet, EE.; Hughes, MD.; Waalkens, HJ.; Duiverman, EJ. \& Kerrebijn, KF. (1994). Remission of childhood asthma after long-term treatment with an inhaled corticosteroid [budesonide]: can it be achieved? Dutch CNSLD Study Group. Eur Respir J. Vol.7, No.1, (January 1994), pp.63-68. ISSN 09031936.

[121] van Rensen, EL.; Evertse, CE.; van Schadewijk, WA.; van Wijngaarden, S.; Ayre, G.; Mauad, T.; Hiemstra, PS.; Sterk, PJ. \& Rabe, KF. (2009). Eosinophils in bronchial mucosa of asthmatics after allergen challenge: effect of anti-IgE treatment. Allergy. Vol. 64, No.1, (January 2009), pp.72-80, ISSN 0105-4538.

[122] Verrills, NM.; Irwin, JA.; He, XY.; Wood, LG.; Powell, H.; Simpson, JL.; McDonald, VM.; Sim, A. \& Gibson, PG. Identification of Novel Diagnostic Biomarkers for Asthma and Chronic Obstructive Pulmonary Disease. (2011). Am J Respir Crit Care Med. Vol.183, No. 12, (June 2011), pp.1633-1643, ISSN 1073-449X.

[123] Vijverberg, SJ.; Koenderman, L.; Koster, ES.; van der Ent, CK.; Raaijmakers, JA. \& Maitland-van der Zee, AH. (2011). Biomarkers of therapy responsiveness in asthma: pitfalls and promises. Clin Exp Allergy. Vol. 41, No.5, (May 2011), pp.615629, ISSN 1365-2222. 
[124] Wang, F.; He, XY, Baines, KJ.; Gunawardhana, LP.; Simpson, JL.; Li, F. \& Gibson, PG. (2011). Different inflammatory phenotypes in adults and children with acute asthma. Eur Respir J. Jan 13. [Epub ahead of print].

[125] Ward, C.; Reid, DW.; Orsida, BE.; Feltis, B.; Feltis, B.; Ryan, VA.; Johns, DP. \& Walters, EH. (2005). Inter-relationships between airway inflammation, reticular basement memebrane thikening and bronchial hyper-reactivity to methacholine in asthma: a systematic bronchoalveolar lavage and airway biopsy analysis. Clin Exp Allergy. Vol. 35, No.12, (December 2005), pp. 1565-1571, ISSN 1365-2222.

[126] Wenzel, SE. (2006). Asthma: defining of the persistent adult phenotypes. Lancet. Vol. 368, No. 9537, (August 2006), pp. 804-813, ISSN 0140-6736. 


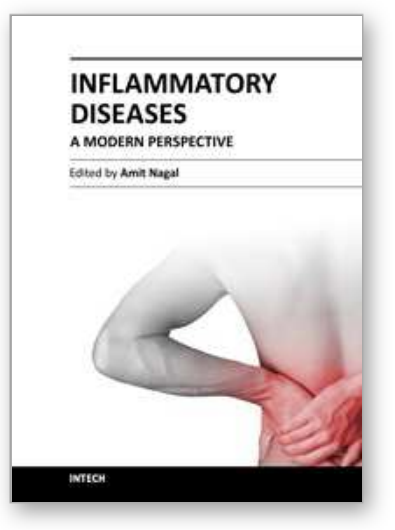

\author{
Inflammatory Diseases - A Modern Perspective \\ Edited by Dr. Amit Nagal
}

ISBN 978-953-307-444-3

Hard cover, 240 pages

Publisher InTech

Published online 16, December, 2011

Published in print edition December, 2011

"Inflammatory Diseases - A Modern Perspective" represents an extended and thoroughly revised collection of papers on inflammation. This book explores a wide range of topics relevant to inflammation and inflammatory diseases while its main objective is to help in understanding the molecular mechanism and a concrete review of inflammation. One of the interesting things about this book is its diversity in topics which include pharmacology, medicine, rational drug design, microbiology and biochemistry. Each topic focuses on inflammation and its related disease thus giving a unique platform which integrates all the useful information regarding inflammation.

\title{
How to reference
}

In order to correctly reference this scholarly work, feel free to copy and paste the following:

J. Bellido-Casado (2011). A New Era for Assessing Airway Diseases: New Insights in the Asthma Paradigm, Inflammatory Diseases - A Modern Perspective, Dr. Amit Nagal (Ed.), ISBN: 978-953-307-444-3, InTech, Available from: http://www.intechopen.com/books/inflammatory-diseases-a-modern-perspective/a-new-era-forassessing-airway-diseases-new-insights-in-the-asthma-paradigm

\section{INTECH}

open science | open minds

\section{InTech Europe}

University Campus STeP Ri Slavka Krautzeka 83/A 51000 Rijeka, Croatia Phone: +385 (51) 770447

Fax: +385 (51) 686166 www.intechopen.com

\section{InTech China}

Unit 405, Office Block, Hotel Equatorial Shanghai No.65, Yan An Road (West), Shanghai, 200040, China 中国上海市延安西路65号上海国际贵都大饭店办公楼 405 单元 Phone: +86-21-62489820

Fax: $+86-21-62489821$ 
(C) 2011 The Author(s). Licensee IntechOpen. This is an open access article distributed under the terms of the Creative Commons Attribution 3.0 License, which permits unrestricted use, distribution, and reproduction in any medium, provided the original work is properly cited. 